\title{
Pengaruh Latihan Menggunakan Simulator Sepeda Berbasis Virtual Reality Pada Keseimbangan Dan Gaya Berjalan Penderita Pasca Stroke
}

\author{
Muh. Fuad Al Haris \\ Jurusan Informatika \\ Politeknik Negeri Banyuwangi \\ Banyuwangi, Indonesia \\ f_haris@poliwangi.ac.id \\ Dianni Yusuf \\ Jurusan Informatika \\ Politeknik Negeri Banyuwangi \\ Banyuwangi, Indonesia \\ dianniyusuf@poliwangi.ac.id
}

\author{
Eka Mistiko Rini \\ Jurusan Informatika \\ Politeknik Negeri Banyuwangi \\ Banyuwangi, Indonesia \\ ekamrini@poliwangi.ac.id \\ I Putu Dody Lesmana \\ Jurusan Teknologi Informasi \\ Politeknik Negeri Jember \\ Jember, Indonesia \\ dody@polije.ac.id
}

\begin{abstract}
Impaired balance and gait are major problems in post-stroke physical therapy due to lack of motor, sensory and cognitive coordination. The purpose of this research was to determine the effect of using a virtual reality augmented cycling simulator in training post-stroke balance and gait. he research subjects involved 10 post-stroke patients who were randomly assigned to the test group $(n=5)$ and the control group $(n=5)$. All subjects who did walking exercises with the help of a physiotherapist for 20 minutes, while the trial group received additional VRAC exercises for 20 minutes, 5 times a week for 1 month.. Balance assessment is carried out using the Berg Balance Scale (BBS) and gait assessment using 10-MWT. From the trial results, it was found that the BBS and 10-MWT values of the test group experienced a significant increase compared to the control group. This suggests that the use of the VRAC simulator in stroke physical therapy can improve balance and gait so that it is suitable for further clinical use.
\end{abstract}

Keywords-balance; gait; VRAC; BBS; 10-MWT

Abstrak-Gangguan keseimbangan dan gaya berjalan merupakan masalah utama pada terapi fisik pasca stroke akibat kurangnya koordinasi saraf motorik, sensorik, dan kognitif. Tujuan penelitian ini adalah mengetahui pengaruh penggunaan simulator sepeda berbasis virtual reality dalam melatih keseimbangan dan gaya berjalan pasca stroke. Subjek penelitian melibatkan 10 penderita pasca stroke yang secara acak dibagi dalam kelompok uji $(n=5)$ dan kelompok kontrol $(n=5)$. Semua subjek melakukan latihan berjalan dengan bantuan fisioterapis selama 20 menit, sedangkan kelompok uji coba mendapatkan tambahan latihan VRAC selama 20 menit, 5 kali seminggu selama 1 bulan. Penilaian keseimbangan dilakukan menggunakan Berg Balance Scale (BBS) dan penilaian gaya berjalan menggunakan 10-MWT. Dari hasil uji coba didapatkan bahwa nilai BBS dan 10-MWT dari kelompok uji mengalami kenaikan yang signifikan dibandingkan kelompok kontrol. Hal ini menunjukkan bahwa penggunaan simulator VRAC dalam terapi fisik stroke dapat memperbaiki keseimbangan dan gaya berjalan sehingga sesuai digunakan secara klinis lebih lanjut.

Kata kunci-keseimbangan; gaya berjalan; VRAC; BBS; 10 MWT

\section{PENDAHULUAN}

Gangguan keseimbangan dan gaya berjalan pasca stroke merupakan penghalang utama bagi penderita stroke yang menyebabkan gangguan atau kesulitan dalam berjalan atau berpindah dari satu posisi ke posisi lain [1][2]. Hal ini disebabkan oleh gangguan pada fungsi koordinasi saraf otak dengan otot motorik, sensorik, dan kognitif yang membuat penderitanya sulit menggerakkan anggota tubuh dengan baik [3][4]. Gerakan tubuh yang tidak teratur dan sulit dikendalikan menyebabkan penderita pasca stroke mengalami kesulitan dalam menjalani aktivitas sehari-hari [5]. Oleh karena itu, terapi fisik untuk melatih keseimbangan dan gaya berjalan merupakan tujuan utama rehabilitasi stroke $[2][3][6]$.

Untuk mengatasi permasalahan yang ada, maka dikembangkan pemanfaatan teknologi virtual reality (VR) pada latihan terapi fisik pasca stroke menggunakan sepeda, dimana bersepeda merupakan aktivitas yang mendekati sama dengan berjalan dan mudah dilakukan tanpa harus berpindah tempat. [7][8] mengembangkan sistem VR bersepeda statik untuk memperbaiki keseimbangan tubuh bagi penderita pasca stoke dengan mendeteksi ketidaksimetrisan pada tekanan telapak kaki ketika mengayuh pedal (bilateral pedal force). [9][10] menggunakan audio dan penanda jalan (road marker) dalam VR bersepeda untuk melatih gerak motorik otot dan meningkatkan motivasi dan ketertarikan penderita pasca stroke dan Parkinson untuk mengikuti pola latihan yang diberikan. [11][12] mengembangkan kursi roda berpedal berbasis VR bagi penderita pasca stroke untuk melatih keseimbangan tekanan kaki menggunakan sensor accelerometer, putaran pedal dengan rotari encoder dan kontrol stir kursi roda untuk menghindari halangan dalam VE. Dari hasil penelitian yang telah dilakukan, penggunaan teknologi VR pada latihan bersepeda statik dapat meningkatkan kekuatan otot, memperbaiki keseimbangan tubuh dan gaya berjalan, tetapi belum pernah diuji pada penderita kronik stroke dengan kecepatan berjalan antara $0.56-1.10 \mathrm{~m} / \mathrm{s}$.

Pada penelitian sebelumnya telah dikembangkan prototip perangkat simulator virtual reality augmented cycling 
(VRAC) yang terbukti meningkatkan luas gerak sendi dan kekuatan otot, tetapi juga mencapai kebugaran kardiorespirasi $\left(\mathrm{VO}_{2}\right.$ Maksimal) [13][14][15]. Dalam penelitian ini, akan diuji penggunaan simulator VRAC untuk melatih keseimbangan dan gaya berjalan pada penderita kronik stroke dimana penilaian hasil uji coba latihan akan diukur menggunakan BBS (Berg Balance Scale) untuk melihat sejauh mana pencapaian keseimbangan [16] dan 10MWT (10-Minutes Walking Test) [17] untuk melihat sejauh mana perbaikan gaya berjalan pada penderita pasca stroke.

\section{METODE}

\section{A. Perangkat Virtual Reality Augmented Cycling (VRAC)}

Perangkat VRAC yang digunakan untuk melatih keseimbangan dan gaya berjalan pada penderita pasca stroke dalam penelitian ini dirancang sesuai dengan [13] dan ditunjukkan Gambar 1.

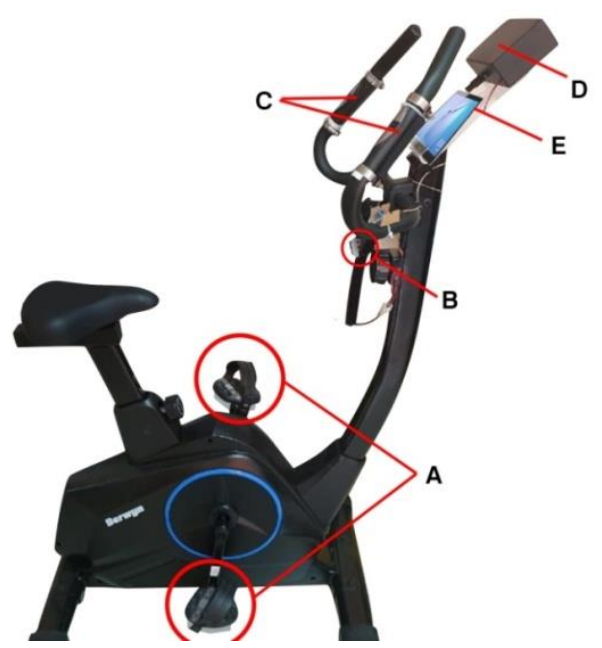

Gambar 1. Perangkat simulator VRAC: A) modul keseimbangan dan gaya berjalan; B) modul pengukur denyut jantung; C) modul kendali stir; D) modul akusisi dan pengolah data; E) modul penampil simulasi

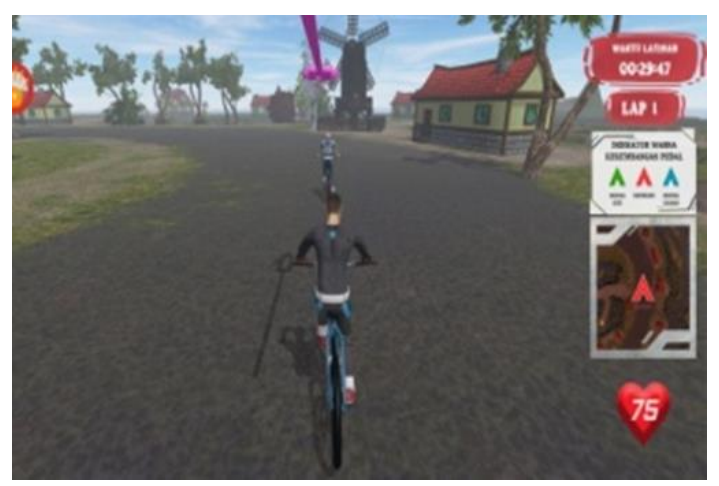

Gambar 2. Lingkungan virtual perangkat simulator VRAC

Perangkat simulator VRAC ini memiliki modul pengukur keseimbangan menggunakan load cell dan gaya berjalan menggunakan accelerometer untuk mendeteksi kemiringan kaki pada posisi dorsi dan plantar flexion dimana kedua sensor diletakkan sebagai alas pada kedua pedal sepeda statik. Untuk menjaga keamanan pengguna selama latihan menggunakan VRAC digunakan pengukur denyut jantung (dalam satuan BPM / beat-per-minutes) agar tidak melebihi denyut jantung maksimal sesuai protokol YMCA [18]. Sedangkan cara kendali stir kiri dan kanan dilakukan dengan sistem tombol on-off yang masing-masing terletak di stir bagian kiri dan stir bagian kanan. Akusisi data dari masingmasing sensor pada modul penyusun VRAC dilakukan melalui nirkabel yang diteruskan ke kotak pengontrol, dimana hasil akusisi data akan dilakukan pengolahan dan ditampilkan pada lingkungan virtual VRAC pada layar tablet pada Gambar 2.

\section{B. Subjek Penelitian}

Penelitian ini dirancang secara randomisasi dan penilaian penilitian dilakukan secara double-blind. Randomisasi dilakukan untuk membagi subjek penelitian $(n=10)$ dalam dua kelompok yaitu kelompok kontrol $(n=5)$ dan kelompok uji $(n=5)$ dengan kriteria subjek penelitian telah mengalami pasca stroke dengan gangguan pada ekstremitas bawah dan seluruh subjek telah menandatangani informed consent untuk menyelesaikan penelitian ini. Double-blind digunakan untuk memperkecil bias pengukuran dengan mengabaikan apakah subjek penelitian mengalami intervensi atau non-intervensi. Seluruh prosedur penelitian telah mendapatkan persetujuan dari komisi etik kedokteran Rumah Sakit Daerah dr Soebandi Jember.

Kriteria inklusi penelitian adalah adanya hemiparesis sekunder akibat stroke yang terjadi dalam 6 bulan terakhir, kemampuan berjalan $0.55-1.11 \mathrm{~m} / \mathrm{s}$ mandiri dengan atau tanpa alat bantu, kemampuan untuk berkomunikasi dan memahami, tidak ada gangguan penglihatan, tidak memiliki gangguan muskoletal yang dapat mempengaruhi kemampuan dalam berjalan, dan memiliki nilai MMSE (Mini Mental State Examination) lebih besar dari 21. MMSE digunakan untuk menilai fungsi kognitif, kemampuan berpikir, dan kemampuan untuk melakukan aktivitas sehari-hari melalui proses wawancara langsung kepada subjek penelitian. Subjek yang tidak memenuhi kriteria inklusi dikeluarkan dalam penelitian. Kriteria subjek yang terlibat dalam penelitian ini ditunjukkan pada Tabel 1.

TABEL 1. KARAKTERISTIK SUBJEK PENELITIAN

\begin{tabular}{|l|c|c|}
\hline & $\begin{array}{c}\text { Kelompok Kontrol } \\
(\mathbf{n = 5})\end{array}$ & $\begin{array}{c}\text { Kelompok Uji Coba } \\
(\mathbf{n = 5})\end{array}$ \\
\hline $\begin{array}{l}\text { Jenis kelamin } \\
\text { (pria/wanita) }\end{array}$ & $3 / 2$ & $3 / 2$ \\
\hline Umur (tahun) & $60 \pm 6$ & $63 \pm 6$ \\
\hline Berat (kg) & $67 \pm 10$ & $70 \pm 10$ \\
\hline Tinggi (cm) & $168 \pm 6$ & $165 \pm 7$ \\
\hline MMSE & $26 \pm 2$ & $26 \pm 2$ \\
\hline
\end{tabular}

Subjek secara acak dikelompokkan dalam dua kelompok, yaitu kelompok kontrol dan kelompok uji coba dengan jumlah maksimal anggota setiap kelompok terdiri dari 5 subjek. Evaluasi dan data dianalisis oleh ahli fisioterapis. Semua peserta dilakukan evaluasi penilaian keseimbangan menggunakan BBS dan penilaian gaya berjalan menggunakan 10-MWT sebelum dilakukannya pelatihan dan dinilai ulang setelah satu bulan melakukan pelatihan. Semua subjek menerima latihan berjalan dengan bantuan fisioterapis selama 20 menit, 5 kali seminggu selama 1 bulan, sedangkan semua subjek yang masuk dalam kelompok uji coba mendapatkan tambahan latihan menggunakan VRAC selama 20 menit, 5 kali seminggu selama 1 bulan.

\section{Prosedur Uji Coba}

Sebelum memulai VRAC, pengguna duduk pada sadel sepeda dengan posisi knee flexion pada $75^{\circ}$, badan berada pada posisi tegap, dan kedua tangan masing-masing memegang stir sepeda kiri dan kanan pada bagian kendali stir yang dilengkapi tombol on-off. Selanjutnya, pengguna 
memilih skenario yang tersedia pada simulator VRAC. Setiap skenario latihan sepeda menggunakan VRAC memiliki tiga tahapan, yaitu pemanasan, latihan, dan pendinginan. Selama tahap pemanasan dan pendinginan, pengguna bersepeda dengan beban $0.5 \mathrm{~kg}$ pada putaran 50 RPM dan mengatur denyut jantung antara 20-30BPM di atas denyut jantung istirahat (resting heart-rate / RHR) yang diukur sebelum tahap pemanasan dimulai. Pada tahap latihan, subjek (rider) bersepeda dibelakang virtual trainer dengan kecepatan 50-60 RPM tanpa henti dan menjaga jarak aman yang telah ditentukan dan mengatur denyut jantung dengan tidak melebihi denyut jantung target. Besar resistansi yang digunakan adalah 25-30 W. Latihan ini dilakukan selama 20 menit, 5 kali seminggu selama satu bulan.

Kemampuan dalam menyeimbangkan pedal VRAC dinilai menggunakan BBS (skala 0-56). Prosedur penilaian pengukuran BBS mengikuti aturan [19], dimana memiliki lima poin penilaian, yaitu " 0 " menunjukkan tingkat terendah dan "4" menunjukkan tingkat tertinggi. Terdapat 14 parameter BBS yang diukur, yaitu 1) duduk ke berdiri; 2) berdiri tanpa penyangga; 3) duduk tanpa penyangga; 4) berdiri ke duduk; 5) berpindah; 6) berdiri dengan mata tertutup; 7) berdiri dengan kedua kaki rapat; 8) meraih ke depan dengan lengan terulur maksimal; 9) mengambil objek dari lantai; 10) berbalik untuk melihat ke belakang; 11) berbalik $360^{\circ}$; 12) menempatkan kaki bergantian ke balok; 13) berdiri dengan satu kaki di depan kaki yang lain; 14) berdiri satu kaki. Percobaan pengukuran BBS ini dilakukan sebanyak tiga kali dan kemudian dihitung nilai rata-ratanya.

Sedangkan pemeriksaan gaya berjalan digunakan prosedur 10-MWT dengan mengukur panjang langkah. Sebanyak tiga kali percobaan dan dihitung rata-ratanya. Langkah-langkah 10-MWT meliputi 1) subjek diminta berjalan di atas tempat yang sudah ditandai dengan pita; 2) untuk menghilangkan komponen percepatan dan perlambatan yang terjadi di awal dan akhir berjalan, subjek diminta berjalan 1.2 meter sebelum tanda mulai dan berhenti 1.2 meter setelah tanda selesai; 3) mencatat waktu yang diperlukan untuk berjalan dengan jarak 10 meter dan banyaknya langkah subjek dicatat; 4) subjek berjalan dengan kecepatan yang nyaman.

Data yang telah diambil menggunakan BBS dan 10MWT dari setiap subjek dilakukan analisis menggunakan SPSS (Statistical Package for the Social Sciences).

\section{HASIL DAN PEMBAHASAN}

Dari Tabel 1 diketahui bahwa tidak ada perbedaan secara signifikan pada kedua kelompok subjek penelitian. Sedangkan berdasarkan hasil uji coba yang ditunjukkan pada Tabel 2 dapat diketahui bahwa kelompok uji coba menunjukkan peningkatan signifikan dalam nilai BBS dan 10-MWT setelah intervensi ( $\mathrm{p}<0.05)$, sedangkan kelompok kontrol menunjukkan kenaikan pada nilai 10-MWT, tetapi tidak mengalami kenaikan secara signifikan pada nilai BBS $(\mathrm{p}<0.05)$. Selain itu, kelompok uji coba menunjukkan peningkatan yang lebih besar dibandingkan kelompok kontrol dari tiga kali hasil pengukuran BBS dan 10-MWT. Hal ini menguatkan dan mendukung hasil penelitian [20][21][22] bahwa penggunaan media virtual reality seperti pada simulator VRAC dapat mempercepat pemulihan keseimbangan dan gaya berjalan pada penderita pasca stroke apabila dibandingan terapi konvensional. Ini menunjukkan bahwa simulator VRAC dapat digunakan secara klinis lebih lanjut.
TABEL 2. PERBANDINGAN HASIL TERAPI KESEIMBANGAN DAN GAYA BERJALAN PADA KELOMPOK KONTROL DAN KELOMPOK UJI COBA

\begin{tabular}{|c|c|c|}
\hline & $\begin{array}{c}\text { Kelompok } \\
\text { Kontrol }(n=5)\end{array}$ & $\begin{array}{c}\text { Kelompok Uji } \\
\text { Coba }(n=5)\end{array}$ \\
\hline \multicolumn{3}{|l|}{ BBS (Berg Balance Scale) } \\
\hline $\begin{array}{l}\text { - Tahap sebelum latihan } \\
\text { (pre-training) }\end{array}$ & $37.12 \pm 5.67$ & $36.21 \pm 5.104$ \\
\hline $\begin{array}{l}\text { - Tahap sesudah latihan } \\
\text { (post-training) }\end{array}$ & $37.50 \pm 5.68$ & $37.96 \pm 5.71$ \\
\hline - Pre-training - post-training & $0.40 \pm 0.88$ & $1.75 \pm 1.52$ \\
\hline \multicolumn{3}{|l|}{ 10-MWT } \\
\hline $\begin{array}{l}\text { - Tahap sebelum latihan } \\
\text { (pre-training) }\end{array}$ & $45.99 \pm 13.28$ & $44.81 \pm 18.46$ \\
\hline $\begin{array}{l}\text { - Tahap sesudah latihan } \\
\text { (post-training) }\end{array}$ & $43.102 \pm 12.10$ & $37.80 \pm 15.76$ \\
\hline - Pre-training - post-training & $1.96 \pm 3.13$ & $7.02 \pm 7.02$ \\
\hline
\end{tabular}

\section{KESIMPULAN}

Tujuan dilakukannya penelitian ini adalah untuk menguji efektifitas latihan fisik untuk memperbaiki keseimbangan dan gaya berjalan pada penderita pasca stroke kronik menggunakan simulator VRAC. Dari hasi uji coba menunjukkan bahwa penggunaan simulator VRAC yang dipadu dengan rehabilitasi konvensional memberikan hasil yang lebih baik dalam memperbaiki keseimbangan dan gaya berjalan pasca stroke dibandingan hanya menggunakan rehabilitasi konvensional saja.

\section{REFERENSI}

[1] van Dijk, M. M., Sandstad, S., Ghosh, N., Dejaeger, E., Beyens, H., \& Verheyden, G. (2015). Diagonal and lateral limits of stability post stroke show a significant relation with gait, balance and the risk of falling. Physiotherapy, 101, e1572-e1573.

[2] Assayag, E. B., Shenhar-Tsarfaty, S., Kliper, E., Hallevi, H., Shopin, L., Bornstein, N. M., ... \& Weiss, A. (2013). Balance and gait measures as predictors of cognitive function in post-stroke patients. Journal of the Neurological Sciences, 333, e251.

[3] Yamasaki, H. R., An, Q., Kinomoto, M., Takahashi, K., Fujii, T., Kogami, H., ... \& Sonoo, M. (2019). Organization of functional modularity in sitting balance response and gait performance after stroke. Clinical Biomechanics, 67, 61-69.

[4] Katz-Leurer, M., Sender, I., Keren, O., \& Dvir, Z. (2006). The influence of early cycling training on balance in stroke patients at the subacute stage. Results of a preliminary trial. Clinical rehabilitation, 20(5), 398-405.

[5] Chang, J. T., Morton, S. C., Rubenstein, L. Z., Mojica, W. A., Maglione, M., Suttorp, M. J., ... \& Shekelle, P. G. (2004). Interventions for the prevention of falls in older adults: systematic review and meta-analysis of randomised clinical trials. Bmj, 328(7441), 680 .

[6] Yang, Y. R., Tsai, M. P., Chuang, T. Y., Sung, W. H., \& Wang, R. Y. (2008). Virtual reality-based training improves community ambulation in individuals with stroke: a randomized controlled trial. Gait \& posture, 28(2), 201-206.

[7] Yin, C., Hsueh, Y. H., Yeh, C. Y., Lo, H. C., \& Lan, Y. T. (2016). A Virtual Reality- Cycling Training System for Lower Limb Balance Improvement. BioMed research international, 2016.

[8] Lo, H. C., Hsueh, Y. H., Yeh, C. Y., \& Chen, S. L. (2011, June). Development of a virtual reality leg-cycling training system for stroke patients. In Virtual Rehabilitation (ICVR), 2011 International Conference on (pp. 1-2). IEEE.

[9] Gallagher, R., Damodaran, H., Werner, W. G., Powell, W., \& Deutsch, J. E. (2016). Auditory and visual cueing modulate cycling speed of older adults and persons with Parkinson's disease in a Virtual Cycling (V-Cycle) system. Journal of neuroengineering and rehabilitation, 13(1), 77 .

[10] Gallagher, R., Werner, W. G., Damodaran, H., \& Deutsch, J. E. (2015, June). Influence of cueing, feedback and directed attention on cycling in a virtual environment: Preliminary findings in healthy adults and persons with Parkinson's disease. In Virtual Rehabilitation Proceedings (ICVR), 2015 International Conference on (pp. 11-17). IEEE 
[11] Suqita, N., Yoshizawa, M., Kojima, Y., Tanaka, A., Abe, M., Homma, N., Kikuchi, K., Seki, K., \& Handa, Y. (2013, March). Evaluation of navigation skill of elderly people using the cycling wheel chair in a virtual environment. In Virtual Reality (VR), 2013 IEEE (pp. 125-126). IEEE.

[12] Sugita, N., Kojima, Y., Yoshizawa, M., Tanaka, A., Abe, M., Homma, N., Seki, K., \& Handa, N. (2012, August). Development of a virtual reality system to evaluate skills needed to drive a cycling wheel-chair. In Engineering in Medicine and Biology Society (EMBC), 2012 Annual International Conference of the IEEE (pp. 6019-6022). IEEE.

[13] Al Haris, M. F., \& Rini, E. M. (2018). Perancangan Dan Validasi Modul Penyusun Serious Game Berbasis Sepeda Virtual Untuk Rehabilitasi Pasca Stroke. Jurnal Teknologi Informasi dan Terapan (JTIT), 5(2), 113-120.

[14] Lesmana, I. P. D. (2019). Panduan Uji Ketahanan Kardiorespiratorik Dengan Menggunakan Simulator VRAC (Virtual Reality Augmented Cycling). Diakses dari https://ehakcipta.dgip.go.id/index.php/c?code=ls21SKjTCCXpB3C0LyqBIbm WrDN6xK\%2FAvrJh25UjOjQ\%3D

[15] Lesmana, I. P. D., Widiawan, B., \& Hartadi, D. R. (2020, July). Manipulation of Virtual Environment to Examine Perception and Vision Aspects of Individuals Post-Stroke When Driving VRAC Simulator. In Journal of Physics: Conference Series (Vol. 1569, No. 2, p. 022010). IOP Publishing.

[16] Blum, L., \& Korner-Bitensky, N. (2008). Usefulness of the Berg Balance Scale in stroke rehabilitation: a systematic review. Physical therapy, 88(5), 559-566.

[17] Datta, D., Ariyaratnam, R., \& Hilton, S. (1996). Timed walking testan all-embracing outcome measure for lower-limb amputees? Clinical rehabilitation, 10(3), 227-232.

[18] Beekley, M. D., Brechue, W. F., Dehoyos, D. V., Garzarella, L., Werber-Zion, G., \& Pollock*, M. L. (2004). Cross-validation of the YMCA submaximal cycle ergometer test to predict VO2max. Research quarterly for exercise and sport, 75(3), 337-342.

[19] Kornetti, D. L., Fritz, S. L., Chiu, Y. P., Light, K. E., \& Velozo, C. A. (2004). Rating scale analysis of the Berg Balance Scale. Archives of physical medicine and rehabilitation, 85(7), 1128-1135.

[20] Mohammadi, R., Semnani, A. V., Mirmohammadkhani, M., \& Grampurohit, N. (2019). Effects of virtual reality compared to conventional therapy on balance poststroke: a systematic review and meta-analysis. Journal of Stroke and Cerebrovascular Diseases, 28(7), 1787-1798.

[21] Plummer, P. (2017). Gait and balance training using virtual reality is more effective for improving gait and balance ability after stroke than conventional training without virtual reality [synopsis]. Journal of physiotherapy, 63(2), 114-114.

[22] Pang, M. Y. (2014). Use of virtual reality in balance and gait training post-stroke. Hong Kong Physiotherapy Journal, 2(32), 49. 